\title{
Perceptions of the EU's Role in the Ukraine-Russia and the Israel-Palestine Conflicts: A Biased Mediator?
}

\author{
Ole Elgström, ${ }^{a}$ Natalia Chaban, ${ }^{b}$ Michèle Knodt, ${ }^{c}$ Patrick Müller, ${ }^{d}$ and \\ Sharon Pardo ${ }^{e}$ \\ aLund University, Paradisgatan 2, Lund, Sweden \\ bUniversity of Canterbury, 20 Kirkwood Ave, Upper Riccarton, Christchurch \\ 8041, New Zealand \\ 'Technical University Darmstadt, Karolinenpl. 5, 64289 Darmstadt, Germany \\ dUniversity of the Basque Country, Barrio Sarriena, s/n, 48940 Lejona, Vizcaya, \\ Spain \\ 'Ben-Gurion University of the Negev, Р.о.в. 653, Beer-Sheva 8410501, Israel \\ ole.elgstrom@svet.lu.se; natalia.chaban@canterbury.ac.nz; knodt@pg.tu- \\ darmstadt.de; patrick.muller@ehu.eus;pardos@bgu.ac.il
}

Received 16 June 2017; accepted 19 November 2017

* Ole Elgström is Professor Emeritus of Political Science at Lund University, Sweden. He has published widely on internal and international negotiations involving the EU, and notably on external perceptions of the EU and its foreign policy roles.

** Natalia Chaban is a full Professor and Jean Monnet Chair at the National Centre for Research on Europe/ Department of Global, Cultural and Languages Studies at the University of Canterbury, New Zealand. Her research focuses on image and political communication studies within international relations contexts. She is a leading expert in the field of EU external perceptions within EU foreign policy studies.

*** Michèle Knodt is a full professor and Jean Monnet Professor ad personam for "Comparative Politics and European Integration" at the Technical University Darmstadt and Director of the Jean Monnet Centre of Excellence "EU in Global Dialogue" (CEDI). Her research focuses on EU external governance.

***** Patrick Müller is a Research Fellow at the Faculty for Social Science at the University of the Basque Country (UPV/EHU)/Ikerbasque Foundation for Science. His research interests include the European Union's external relations, global governance, Mediterranean politics and conflict resolution.

***** Sharon Pardo is a Jean Monnet Chair ad personam Professor at the Department of Politics and Government, Ben-Gurion University of the Negev.

(C) OLE ELGSTRÖM, NATALIA CHABAN, MICHÈLE KNODT, PATRICK MÜLLER AND

SHARON PARDO, 2018 | DOI 10.1163/15718069-23021154

This is an open access article distributed under the terms of the prevailing CC-BY license at the time of publication. 


\begin{abstract}
This article focuses on how the European Union's (EU) mediation activities during the Russia-Ukraine and Israel-Palestine conflicts are perceived by local elites. Our analysis is based on recent interviews with decision makers in Ukraine, Israel and Palestine. Consistent with this special issue, we investigate perceptions of EU roles, strategies and effectiveness. We suggest that the EU's relation to the parties may affect their perceptions of EU conflict mediation efforts. Specifically, we expect that the EU is perceived as a biased mediator in both cases due to perceived close relations to one or more conflict parties. However, contrary to our expectations and widespread assumption in mediation theory, while such a bias exists, we found it is not perceived as a main cause of EU ineffectiveness. Other factors, including the prominence of other mediators and internal E $\mathrm{U}$ disunity, are perceived as more detrimental to EU efficacy.
\end{abstract}

\title{
Keywords
}

European Union (EU) - mediator - EU external perceptions - Russia-Ukraine conflict Israel-Palestine conflict

A blind spot in the literature on the $\mathrm{EU}$ as a mediator is research on the perception of this role. We believe that an analysis of perceptions, in particular the perceptions of the parties to the mediated conflict, adds an indispensable perspective to objective examinations of the EU's mediator role. If the $\mathrm{EU}$ is to be an effective mediator, it is of vital importance that its brokerage activities are seen as legitimate, relevant and effective by the conflicting parties.

The article focuses on how the Eu's mediation activities during the RussiaUkraine and Israel-Palestine conflicts are perceived and interpreted by local elites. Our analysis is based on recent interviews with 80 decision makers across Ukraine, Israel and Palestine. ${ }^{1}$ Consistent with the thrust of this special issue of International Negotiation, we investigate perceptions of EU roles, strategies, partiality and effectiveness with the help of role theory. Roles refer to patterns of expected behavior. They are determined by both an actor's own

1 Our team of co-authors would like to express gratitude to the team of researchers who collected the elite opinion data within the framework of the Jean Monnet Network "Crisis, Conflict and Critical Diplomacy: Eu Perceptions in Ukraine, Israel, Palestine ( $\left.\mathrm{C}_{3} \mathrm{EU}\right)$ :" Ido Rosenblum (who collected data in Israel), Dr. Yevheniia Hobova, Dr. Viktor Velivchenko, Dr. Anastasiya Pshenychnykh, and Dr. Hanna Kryvenko (who collected the data in Ukraine). 
conceptions of appropriate behavior and the expectations of other actors. Both role conceptions and expectations may be affected by the actor's role performance - how its role actually plays out in specific contexts. Perceptions and expectations may relate to mediator strategies (types of mediation; degree of active involvement) and mediator (im)partiality. We suggest that the EU's relation to the parties of these two conflicts may affect external perceptions of its mediation in the conflict. Thus, we expect that, in both cases, the EU is perceived as a biased mediator due to the perception of close relations with one or more conflict parties. This perception of bias may have consequences for further perceptions of the Eu's role performance and effectiveness.

We begin with a brief overview on the links between mediator (im)partiality and effectiveness in mediation theory. In the following section, we argue for the importance of studying perceptions of mediator efforts, and introduce role theory as an instrument for highlighting internal and external perceptions of mediator strategies, partiality and effectiveness. Following is a short overview of $\mathrm{EU}$ mediation efforts in the two cases, focusing on the EU's relations with conflict parties. After a discussion of methods and data, we turn to empirical case analyses. We conclude by comparing the cases and drawing general conclusions on external perceptions of the EU's mediator role, underlining the potential effects of perceiving the $\mathrm{EU}$ as a biased mediator.

\section{Biased Mediation}

For many observers, neutrality is seen as a necessary tool in the successful mediator's armory (Carnevale \& Arad 1996: 40-41; Young 1967: 309). Some authors even include neutrality in their definitions of mediation (Bercovitch 1992: 6; Wallensteen \& Svensson 2014: 320). According to these scholars, the third party should preferably have no ties to any conflict parties and no stake whatsoever in the negotiated outcome. These traits supposedly increase the mediator's credibility (Maoz \& Terris 2006: 411), making the mediator acceptable to all parties; enhance the possibility of obtaining information from the disputants; and increase the legitimacy of proposed solutions (Kleiboer 1998: 29). Therefore, neutrality is associated with mediator effectiveness.

The necessity and advantages of neutrality have increasingly been questioned by other mediation scholars, led by the pioneering work of Saadia Touval who argued that bias can also help mediation "under the assumption that the mediator delivers the agreement of the party toward which it is biased" (Zartman 2008: 305; Touval 1975, 1982; Touval \& Zartman 1985, 2007). Touval and others hold that active interventions by a third party affect both the substance 
and likelihood of an agreement. If mediation is conceived as an extension of negotiation, with the mediator as one of the players, it is difficult to associate mediation closely with neutrality (Carnevale \& Arad 1996: 41; Princen 1992: 23). Others claim that (moderate) partiality may actually help reach agreements (Kydd 2003; Savun 2008). One logic is that only mediators believed to be "on your side" can credibly counsel concessions or restraint (Kydd 2003; Savun 2008). Another rationale proposes that neutral mediators are incentivized to hasten a concluded agreement at the expense of quality, whereas biased mediators will ensure that the interests of "their" side are guaranteed (Svensson 2009). In brief, mediation analysts today assert that neutrality is problematic and the effectiveness of neutrality or impartiality is contingent upon context. Impartiality can result in efficacious outcomes under some circumstances, but not under others.

In this article, we use the term "(im)partiality" rather than neutrality, and seek to empirically investigate this trait's potential impact. In particular, we wish to investigate how mediator partiality is perceived and evaluated by conflict parties, and how a perceived bias may impact perceptions of mediator effectiveness. To do so, we understood partiality in three ways. Partiality may rest upon the closeness of current and/or previous ties a mediator holds with disputants: relational partiality. Equally important is processual partiality, where the mediator favors one of the parties during the process, for example by giving privileged information to one party. Finally, outcome partiality means that the mediator deliberately favors one conflicting actor in its settlement proposals, or that the mediator's support for certain principles seems to favor one party and their current positions over another (Elgström et al. 2003).

Understanding (im)partiality is intimately linked to understanding mediation strategies - the ways in which mediators achieve their objectives. Touval and Zartman's (1985) classification is one of the most widely used (Wallensteen \& Svensson 2014: 319). They identify three main strategies - communicationfacilitation, formulation and manipulation - moving from a more passive to an increasingly active or interventionist approach (Bergmann \& Niemann 2015). ${ }^{2}$

Measuring the effectiveness of mediation also poses severe conceptual and methodological problems. Effectiveness is an "essentially contested concept"

2 In communication-facilitation, the mediator may make arrangements for interaction between the parties and serve as a channel of communication. Formulation strategies can involve establishing procedures/protocol, structuring agenda, highlighting common interests and suggesting text formulations. Manipulation may include making substantive proposals, filtering information, suggesting concessions, and even using coercive measures or providing positive incentives (Bercovitch 1992: 17; Bergmann \& Niemann 2015: 962). 
and there is "no Archimedean point from which success and failure can be objectively measured" (Jørgensen 2013: 88, 90; Arensman 2017). Effectiveness can be evaluated both by objective and subjective measures. Subjective measures rely on perceptions of goal attainment or of the mediation outcome's fairness (in itself a concept with several interpretations). In this article, we solely utilize such subjective evaluations - the parties' own assessments of the EU's effectiveness as a mediator. "Real effectiveness" is notoriously difficult to measure and we believe that perceived effectiveness in the context of this research is a suitable indicator, given that the EU must consider and respond to the subjective reactions of the parties involved.

\section{The Mediator Role: A Perceptual Approach}

Our analysis contributes not only to mediation literature, but also to a growing literature on EU external perceptions (for reviews of this area, see Lucarelli 2014; Chaban \& Holland 2015; Elgström \& Chaban 2015). Research that explores various conflicts' party perceptions of the EU as a mediator in the EU's Eastern and Southern neighborhoods remains virtually non-existent, and our analysis addresses this gap. ${ }^{3}$

Role theory is ideal for this purpose as it pays explicit attention to both an actor's self-images and to outsiders' expectations, and engages with expectations referring to both the role itself (here: the mediator) and to the perceived characteristics of the role incumbent (here: the EU). Roles refer to "patterns of expected or appropriate behaviour" (Elgström \& Smith 2006: 5). They are shaped by an actor's role conception - its perception of appropriate behavior given a certain role and context - but also by the expectations of external actors. According to this logic, actors tend to behave how they are expected to in a particular position, situation or context (Holsti 1970: 239-40). Roles and role performance are thus an effect of learning and socialization in interactive negotiation processes where self-conceptions are confronted with others' expectations (Elgström \& Smith 2006; Aggestam 2006). External reactions to an actor's role performance may or may not change its role conceptions.

3 One exception is works by Harpaz and Shamis (2010) and Pardo and Peters (2010) on Israel, which point to ambiguous EU perceptions in the context of the conflict. On one side, it is seen as a mistrusted actor and "illegitimate broker" (Harpaz \& Shamis 2010: 592-93, 599-603) whose involvement in the conflict prevented progress towards peace (Pardo 2010: 72). On the other side, many Israeli emphasize the cultural and economic ties with the $\mathrm{EU}$ and therefore support a more active role for the Union in the peace process (Harpaz \& Shamis 2010: 593). 
Unaltered role performance in the face of continuous external criticism is plausibly detrimental to effectiveness.

We contend that a focus on perceptions, not least external perceptions, brings a deeper and more nuanced understanding of mediation processes than solely studying mediation objectively. In the words of Richmond (1998: 709), "perceptions of ... position and power, aims and relationships, plus the process of mediation, are vital determinants not only of the role that the disputants want the mediator to play, but also of the 'success' of the process." Thus, we argue that other countries' perceptions of the EU as a mediator can facilitate or obstruct the EU's mediation initiatives. Perceptions of legitimacy, credibility and coherence are particularly important in this respect (Elgström \& Chaban 2015; on mediator credibility, see Maoz \& Terris 2006). If the EU is perceived as speaking with many voices and/or as lacking in legitimacy and credibility, the likelihood of being considered an effective mediator decreases. Furthermore, as argued above, a perception of (im)partiality is key to understanding the EU's prospects as mediator. Most observers submit that partiality - in any of the types detailed in the previous section - is a crucial obstacle to effectiveness, as bias to one party may lead to suspicion and distrust from the other. There are, however, scholars that argue that a mediator who has trustful and good relations with one party may use this closeness to invent or produce solutions otherwise not possible (Richmond 1998; Wallensteen \& Svensson 2014), and, others who advocate for a consciously biased and interventionist mediator role, instead of the traditional impartial facilitator role (Kydd 2003; Savun 2008).

\section{EU Mediation in the Two Conflicts}

\section{The $\mathrm{EU}$ and the Russia-Ukraine Conflict}

The Russia-Ukraine conflict, with a focus on Crimea and Eastern Ukraine, started in the beginning of 2014. The conflict must be seen as embedded in the EUUkraine relationship within the framework of the EU European Neighborhood Policy (ENP) and, within that, the Eastern Partnership (EaP) (Ademmer 2014). Contrary to other conflicts involving post-Soviet states (with Russia or among themselves), the EU as mediator has not played the role of an "honest broker" in this conflict (Shelest 2016: 481). Rather, the EU forms a part of the conflict as it pushes for Ukraine's rapprochement towards the Union within the ENP and its EaP. Russia, as expected, opposes this rapprochement (Kanet 2015: 519). It interprets all EaP initiatives as a "Trojan horse" aimed at integrating former 
Soviet states into the North Atlantic Treaty Organization (NATO) (Tsygankov 2015: 12).

The wave of demonstrations and civil unrest in Ukraine (known as "Maidan" or "Revolution of Dignity") in favor of Western integration and democratic reforms began in November 2013 and continued until February 2014. In this period, the EU acted as a much more "consolidated actor" than later in the conflict; the European Commission and the European Parliament succeeded in creating a single position (Shelest 2015: 481). For Ukraine, Maidan marked the starting point of deep divisions between $\mathrm{EU}$ - and Russia-oriented elements in society, resulting in the ousting of President Viktor Yanukovych, and escalating into Russia's annexation of Crimea and armed conflicts in Eastern Ukraine.

Progress towards a resolution of the conflict in Eastern Ukraine is marked by three negotiation formats: Geneva, Normandy and Minsk. In the Geneva format, Ukraine, Russia, the EU and the Us negotiated within the framework of G8 and G20 summits in April 2014 (ICPS 2015: 12). The EU was represented as an organization. However, the agreed measures on conflict de-escalation were unsuccessful (Shelest 2016:483). Subsequently, the Normandy format saw Ukraine, Russia, Germany and France participating, without us involvement (Galbert 2015). Germany and France participated as single players, but also as the voices of the $\mathrm{EU}$ (not represented as an organization then).

The first Minsk Protocol (Minsk I) was negotiated by the trilateral contact group composed of Ukraine, Russia and the Organization for Security and Cooperation in Europe ( ). Neither the EU, Germany nor France were involved. The agreed ceasefire in the Donbas region failed and the trilateral contact group did not serve as an official format in the following processes. In 2015, to stop the violent conflict, another round of negotiations was launched within the Normandy format. "To give the new format more authority, the agreement was negotiated with the top leaders of all participating states personally" (Kostanyan \& Meister 2016: 2). This process led to the Minsk II agreement and has been referred to as the "Minsk format," even though it has the same composition as the Normandy format. The involvement of Germany and France was disputed within the EU: "Poland for many times stated that it would be eager to be involved in these negotiations, as Ukraine needs a stronger support" (Новое время 2015, cited in Shelest 2015: 483). Effectively, a parallel structure of conflict mediation efforts has been established. The trilateral contact group acts simultaneously with negotiations within the Normandy format.

Parallel to its diplomatic efforts, the EU was also involved as a conflict actor through its sanctions policy. In the summer of 2014, the EU imposed sanctions on Russia, as did the US and other Western allies (Kostanyan \& Meister 2016:2). 
The sanctions, prolonged several times since 2014, include financial and economic sanctions and travel bans. Unsurprisingly, the EU's strategic partnership and dialogue with Russia has been impacted and subsequently frozen. Economic sanctions were a controversial subject for some EU Member States due to their economic interests. A unified EU position was found only after heated negotiations. Yet, despite the use of a range of EU mediation strategies including traditional mediation activities often led by Germany and France, elements of coercive diplomacy and the EU acting within the ENP - the EU was "not able to become a real mediator" (Shelest 2016: 481).

\section{The EU and the Israeli-Palestinian Conflict}

For five decades, the EU has invested in building peace between Israelis and the Palestinians. As Israel's major trading partner and the single most important international donor to the Palestinian Authority (PA), the EU has longstanding and well-established ties with both conflict parties. As a block of 28 Member States, the EU also enjoys considerable diplomatic weight, including at the United Nations (UN). Still, despite the EU's considerable potential as a diplomatic mediator, it has traditionally found it challenging to assume such a role.

When the Middle East Peace Process (MEPP) was launched at the Madrid peace conference in 1991, Europe merely provided the venue for peace talks co-sponsored by the US and the USSR at that time. Subsequently, the US established its role as the principal diplomatic mediator in the so-called "Oslo peace process," with the EU playing only a secondary and very limited role (Tocci 2009; Khader 2013). This has been disappointing for the EU. After all, key principles and ideas progressively developed in the EU's declaratory diplomacy such as the involvement of the Palestinian Liberation Organization (PLO) in the peace efforts and the Palestinian right to self-determination, which were expressed in the 1980 Venice declaration ${ }^{4}$ - were later accepted as founding principles governing the Israeli-Palestinian peace process. Developed through a series of landmark declarations over four decades, the Eu's formula for a "just peace" has been remarkably consistent, supporting the right to self-determination of the Israeli and Palestinian people through the creation of a sustainable two-state solution, respecting human rights and international law (Tocci 2009). ${ }^{5}$ Although the Union has been strikingly absent from many concrete

4 The central parts of the Venice Declaration discuss: the Palestinian problem, the status of Jerusalem, and the question of Jewish settlements.

5 The EU was one of the first international actors to recognize the legitimate rights of the Palestine people (1973), its right to self-determination (1980) and to commit itself to the 
peace negotiations (Persson 2013: 209), its political vision, initiatives and commitments have still inspired and influenced the negotiation context and MEPP parties, and should therefore be considered mediation activities.

Following the severe MEPP crisis in the early 200os, the EU took on a more visible mediation role. Importantly, the EU became a member of the Middle East Quartet together with the UN, the Us, and Russia: an international body established in April 2002 for the coordination of international diplomacy toward the Israeli-Palestinian conflict (Tocci 2002). The EU also actively contributed to the establishment of the Quartet's "Roadmap for peace" initiative, which has remained a major reference point for peacebuilding. However, its role in the Quartet has not subsequently translated into a more visible EU in peace negotiations; in fact, it even amplified concerns that the EU mainly follows the Us's lead (Müller 2014). The EU did not play a meaningful diplomatic role in the 2007 "Annapolis initiative," through which then us President George W. Bush sought to revise Israeli-Palestinian peace negotiations; nor did it play a significant role in the mediation efforts under former us Secretary of State John Kerry from 2013-14. Over the last decade, it was individual EU Member States, rather than the EU as a whole, which became actively involved, such as France's initiative to restart Israeli-Palestinian peace negotiations in January 2017 (the so-called "French initiative"). Similarly, individual Member States have taken far-reaching unilateral diplomatic steps, most notably Sweden who recognized the state of Palestine in 2014.

The EU's "problematic role as a mediator" in the MEPP (Persson 2013: 25) has been attributed to the dominance of the US as a mediator, to internal $\mathrm{EU}$ divisions (Tocci 2009: 388), to the Israeli negative (mis)perceptions towards the EU (Harpaz \& Shamis 2010; Pardo 2010, 2015: 1-20) and, to a certain extent, also to Palestinian perceptions towards the Union (Santoro \& Nasrallah 2010; Persson 2013: 216). At the same time, the EU has devoted considerable material resources to building peace between Israel and Palestine. This is based on the EU's bilateral contractual ties with Israel and the PA, especially within the two association agreements that the EU signed with Israel and the PLO on behalf of the PA, as well as within the ENP (Pardo \& Peters 2010; Müller 2012; Reich 2015; Gordon \& Pardo 2015). Yet, the EU's bilateral ties have been criticized for a perceived dissonance between words and deeds, particularly for a lack of willingness to actually use its economic clout vis-à-vis Israel and the PA (Tocci 2009). Given the EU's "no contact policy" toward the Palestinian faction

creation of a Palestinian state (1999) (Persson 2013: 144; Khader 2013). In 2014, the European Parliament decided to support "in principle" the recognition of Palestine as a sovereign state. 
Hamas, which controls the Gaza Strip, its reform efforts of the PA also remain limited to the West Bank.

\section{Methods and Data}

Our analysis of the images of the EU as a conflict mediator examines perceptions among external elites. A focus on elites is a mainstream approach in the studies of EU perceptions (Elgström \& Chaban 2015; Chaban \& Holland 2015). These individuals are considered to be "in positions to make decisions having major consequence" by virtue of "occupy[ing] the strategic command posts of the social structure" (Mills 1956: 3). The dataset on EU external perceptions was gathered through individual, face-to-face, semi-structured interviews with political, business, civil society and cultural elites in Ukraine (40 interviews), Israel (20 interviews) and Palestine (17 interviews). In all three locations, samples included: key politicians involved in shaping interactions of their respective locations with the Eu; business leaders who trade with and engage financially with the EU; leaders of civil society (those who do and do not interact with the EU regularly); and influential cultural personalities. The interviews were conducted in the respective locations between December 2016 and April 2017 by a team of pre-trained researchers. In Ukraine, interviews took place in Kyiv (the capital) and Central and Eastern regions (Cherkasy and Kharkiv regions, respectively). All questionnaires targeted several major themes, including: EU general perceptions; perceptions of bilateral relations with the EU; perceptions of the EU's diplomacy; and perceptions of the $\mathrm{EU}$ as mediator in the respective societies' ongoing conflicts.

Guided by the conceptual model discussed above, our empirical analysis targets images of the $\mathrm{EU}$ as mediator in terms of its perceived strategies, effectiveness and (im)partiality. Three lines of questioning were designed to speak to these concepts, respectively: (1) What characterizes EU mediation efforts in mediating conflict (in your location)? And what characterizes EU Member States' mediation efforts? (2) Has the Eu been an effective mediator? Why/why not? Have EU Member States been effective mediators? and (3) Has the Eu's position in the conflict, including its relations to the conflicting sides, influenced its effectiveness? Answers to these questions, transcribed and translated verbatim, ${ }^{6}$ are discussed below. Following protocol, respondents referenced below will remain anonymous.

6 Interviews in Palestine were conducted in English. 


\section{Findings}

\section{Ukraine}

Reflecting on the Eu's role as a mediator, Ukrainian elites demonstrated different opinions. For some, the Eu's role as a mediator was obvious. A civil society respondent stated, "Europeans have got involved ... they play this game, and try to find a logical solution." The EU was seen as instrumental to facilitating compromises, and also as a controller of the achieved agreements (opinion shared by business elites). In contrast, some respondents rejected the EU's mediator role. According to this view, it was EU Member States who were seen as mediators, not the EU. Germany and France were named here, as members of the Minsk process. Significantly, Poland, Baltic and Scandinavian countries, as well as the $\mathrm{UK}$, were repeatedly acknowledged as contributors to the mediating process.

When the mediating role (of the EU and/or its Member States) was recognized, Ukrainian respondents saw the EU and its states as possessing an arsenal of mediation strategies. In terms of communication/facilitation, the $\mathrm{EU}$, Germany and France were credited for their ability to bring both Ukraine and Russia to the negotiation table. Here, the cognitive "blend" between the EU and its two Member States was rather typical - they are all seen as "Europeans." "Europeans" were also praised for being involved in mediation from the very beginning of the conflict and remaining in the foreseeable future (as one civil society interviewee notes, taking "responsibility"). In addition, European actors were mentioned as facilitators of exchanges. A civil society respondent elaborated, "Europeans regularly come to Kyiv, they even go to Donbas, they are constantly in touch with Ukrainian authorities and Russian authorities."

In terms of the formulation strategy, respondents commented on the role the EU, and specifically Germany and France, played in setting the Minsk and Normandy formats. However, interviewed elites critically reflected on the Minsk format. Responses indicated this format was seen as not working well in the long term (for example, a business leader notes, "As for the Minsk process, these countries sat Russia at the negotiating table, but there is no progress anymore"). But Ukrainian elites agreed that this is the only format available, and that the EU, through its Member States, played a key role in it. In the words of a civil society representative, "no matter how hard the Minsk format is criticized, it is the only format that has preserved a relative peace in Ukraine. In other case, it would have been worse." Finally, in terms of manipulation strategies, a typical response would mention sanctions on Russia. EU financial aid to Ukraine was also mentioned, but only occasionally.

In terms of partiality, Ukrainian respondents saw the EU as favoring Ukraine through providing support to the OSCE mission. Reflections on the EU in terms 
of processual partiality were the least apparent. More reflections concerned relational and outcome partiality. A dichotomy, setting interests versus values, colored the vision of EU partiality in relational terms. Reflections on EU-Russia relations featured a consensus among Ukrainian stakeholders; these relations were seen to be led by economic imperatives and material interests. Bilateral economic interests between the EU and Russia were seen by one civil society respondent as a "factor that limits the abilities of the EU." Some interviewees saw the EU as an "interested person" rather than an impartial mediator, or as one business interviewee argues, "not the most efficient from the point of view of Ukraine ... because the EU's interests are taken into account, too."

Relations with Ukraine were also recognized. The EU had already invested substantially in Ukraine through the ENP (a typical response comes from a representative of Ukraine's cultural sphere: "The EU is actively promoting the idea of membership, of associate membership, of visa liberalization for Ukraine"). These policies were seen to be based on shared values:

The EU also had a strong relationship with Ukraine within this Neighborhood Policy, in the Eastern Partnership framework, so it would not be acceptable for them to leave this game completely.... They have to be engaged ... Of course, there is more interest in Russia, there are more values in Ukraine ... Balancing this is difficult. So far ... the European Union keeps this as a priority, but also tries not to lose the benefit. This is like sitting on two chairs at once (from a civil society leader).

Respondents saw a challenge for the $\mathrm{EU}$, formulated by one civil society interviewee, to "not lose anything with Russia, and to somehow save face with Ukraine." In its choice between interests and values, the EU was not seen as a neutral mediator; it has ties to both actors and is too involved. In terms of outcome partiality, the EU was seen to deliberately favor Ukraine by taking a strict position towards Russia. This policy was considered effective by many: a politician noted that the EU "takes some strict position to which Russia reacts;" a business interviewee echoed, "the EU unanimously imposed and still continues the sanctions against Russia;" and a civil society representative added that it has been "disciplined in executing the sanctions policy."

Ukrainian general perceptions of the EU's effectiveness in the mediation of the conflict featured a range of views. Some respondents noted the EU's "pressure on Russia, its economic and financial support [to Ukraine], and its influence on the Ukrainian political elite" (from a politician) - seen by Ukrainian elites as positively impactful. Yet, such general positive affirmative views were the least visible in our analysis. When positive, perceptions were typically connected to the recognition of the effective role of several Member 
States - Germany and France primarily, but also Poland, the UK, the Baltic and Scandinavian countries. The last group was seen as effective "lobbyists" for Ukraine in the EU. France and the UK were also mentioned by cultural elites as successful actors in facilitating cultural exchanges between Ukraine and Europe - an effective mechanism to remind Ukrainians that there is more than conflict in the world. Here, public and cultural diplomacy, rather than conflict mediation, was deemed effective. However, it was not a typical view.

The most typical was an ambivalent view. The EU was seen as somewhat effective, with opinions divided between those who saw the Eu's effectiveness in a more negative than positive light and vice versa. "Glass half-empty" perceptions seemed more frequent. They featured an image of the EU being tired of the conflict and wanting to settle it quickly - "just to stop shooting" and "just" to have peace at its borders. A short-term solution was not seen as very effective; it would not work long term. The EU's limited understanding of Ukraine and the underlying reasons behind dramatic events was also noted by a business respondent: "One should understand the role of Russia in this conflict, as well as the economic, social, and cultural specific particulars of the region. Without such understanding, it is just impossible to achieve durable peace here." The EU was also not seen as effective in addressing the region's needs, having consequences for the conflict in Ukraine. "Glass half-full" views stressed the initiation of the Minsk format. Despite all its limitations, Germany and France used their international cache and compelled Russia to sit at the negotiation table - a key achievement in the eyes of respondents.

Finally, comments also offered critical views on the EU's effectiveness as a mediator: the conflict is not over and there is no change to the violent situation. Significantly, there was a broader perception that it is not just the EU which is ineffective, but there are actually no effective mediators in these negotiations. In addition, Russia was seen as an exceptionally hard actor to negotiate with. It was described as a party who did not want to resolve the conflict. A divided Europe was mentioned too, with some states being "lobbyists" for Ukraine and some being more supportive of Russia. This division was seen, in the words of one politician, to be "hindering decision making" in the EU regarding the conflict. Finally, respondents noted that the Eu has its own interests at heart, thereby jeopardizing effectiveness.

\section{Israel/Palestine}

The perception of the EU as a mediator in the Israel-Palestinian conflict differed depending on the conflict partner. Some respondents, from both sides, did not perceive any mediation initiatives at all. Overall, the interviews from Israel and Palestine showed a lack of awareness of the EU's role as a conflict mediator. 
When there was awareness, elites in Israel claimed that the general feeling was that there are anti-Israeli sentiments. They stressed the "lack of neutrality" and that the EU is "one-sided towards the Palestinians" whereas "Israeli concerns are ignored," as respondents from the political elite stated, addressing processual partiality. Yet even if Israeli interviewees viewed the EU as biased against Israel, some pointed to the fact that Member States are more important than the EU as conflict mediators. "The real power probably lies in the capitals and not in Brussels," explained an interviewee from the business community. Not all Member States were highlighted as following the anti-Israeli path. In this regard, the German case was mentioned most frequently. "Germany has a feeling of responsibility for the Jewish fate, others don't have this feeling, and the EU doesn't," an interviewee from the Israeli cultural realm stated. Still, relational partiality towards Israel was primarily constructed for the German case. In the case of the EU, as well as in other cases like the UK, partiality towards Palestine was perceived from the Israeli side.

From a Palestinian perspective, the EU itself was not perceived as a biased mediator. The Palestinian interviewees tended to disaggregate the EU and identify Member States in favor of the Palestinian side and of the Israeli side. A business respondent stated: "We have different positions between Member States, for example, France, Ireland, Sweden, they have a clear position supporting the Palestinian cause. Other countries are either hesitant or they consider the Israeli position, and, they are not ready to have a certain position in this conflict, like Germany, Czech Republic, some East European countries." In the same way, a Palestinian political interviewee answered: "I haven't seen the EU playing a mediatory role, I mean the EU is part of the Quartet ... But with the individual countries, several countries are taking up roles. They want to play a role in mediation."

When it came to the question of effectiveness, both the Israeli and Palestinian interviewees agreed that the EU has not been effective as a mediator. On the one hand, they had problems in distinguishing between the EU and its Member States. Most of the interviewees mentioned selected initiatives of Member States, like the French initiative, to point to at least one partially effective effort of one Member State. On the other hand, they pointed out that the EU as such is only part of the Quartet; thus, it is hard to attribute an effect to EU efforts. "I cannot say they were an effective mediator because they are not leading any mediation." The Quartet as such was not evaluated in the interviews but the role of the us was discussed. "At the end of the day even the United States was always taking the lead and never even strengthened the role of the Quartet," answered a business actor. Another one added: "Americans are the leader, in the driving seat." In general, a lack of political assertiveness in promoting its 
position vis-à-vis Israel undermined the effectiveness of the EU in the eyes of Palestinian respondents.

Overall, the judgment of Israeli and Palestinian interviewees was that the EU is not effective, especially compared to other mediators. "The EU is not effective. The members are hardly effective, even though they want to be," an Israeli politician stated. "It is a less central player in the field compared to other powerful countries, moderate Arab countries and the United States," another Israeli politician added. However, respondents attested that the EU "still manages to do more than other international institutions" (a civil society representative).

The interviewees also explained why they perceived a lack of effectiveness in the Eu's mediation efforts. The main reasons identified are strong mediator competitors like the us, as well as internal problems, including the financial and political crises, terrorism, the internal divide between the EU and Member States, and strategic deficits. Comparison with other mediators honed in on the us. "They could play a stronger role but they have accepted they are subordinate to the Americans," a Palestinian political interviewee stated. Concerning the EU's current "difficult times," Palestinian interviewees pointed to the effect of terrorism on the EU. One interviewee from civil society stated: "Maybe fivesix years ago, I saw their role was more powerful ... [T] errorist acts ... affect policy." Disunity within the EU was also mentioned by quite a few interviewees. "The EU is often divided and cannot use its influence ... Some Member States have been more active. Sweden was very brave when it supported Palestinian statehood. France has initiated a peace initiative. But the EU is not influential because it is not a unified actor," a member of the cultural elite in Palestine mentioned. An interviewee from civil society explained that "they cannot change anything on the ground because they are not speaking with one voice." Others stated that EU is not "systematic" and does not have a plan. They just "come and talk." One civil society respondent explained that the Eu's "effectiveness is limited because of the unstable situation right now and the need to survive politically."

\section{Conclusions}

In this study, we have argued that examining the perceptions of conflict parties is key to understanding the nature and effectiveness of mediation efforts. We have most significantly emphasized the effects of being seen as a biased mediator. In both the Ukraine-Russia and Israel-Palestine cases, the EU was perceived as partial to one party. However, this bias was not seen as a main 
cause of perceived EU ineffectiveness. Other factors, including the prominence of other mediators and the internal disunity of the EU, were portrayed as more detrimental. This finding does not necessarily contradict the theoretical position that bias hinders effectiveness, as we do detect certain perceived negative consequences of partiality in both cases. Still, our finding is contrary to our expectations and goes against widespread assumptions in mediation theory. Examining external perceptions of potential mediators thus brings new insights to the study of mediation.

The EU is conceived as playing a mediator role in both conflicts, though respondents in both cases have pointed to the importance of select Member States. Still, in such instances, these states were often perceived as representatives of the Union. Additionally, the EU was seen as utilizing the whole arsenal of mediator strategies. In Ukraine, its role as a facilitator - bringing the conflicting parties to the table and supporting communication between them - was emphasized, but also was its use of material resources in the form of sanctions and economic aid. In the Middle East, the material incentives, especially on the Palestinian side, were well recognized, and the Union's support of an independent Palestinian state within the framework of a two-state solution for two-peoples was highly appreciated.

The majority of our Ukrainian respondents perceived the EU as on its side in the conflict - EU sanctions against Russia being the primary indicator. Still, the effectiveness of the EU's policies, backed by sanctions, was tempered by perceived EU economic self-interest in Russia. Although Ukrainian elites perceived the EU as a biased mediator in their favor, they were not convinced that this will, in the end, protect Ukrainian interests, as the EU was seen to be shortsighted and limited by economic and security concerns. The lack of EU mediator effectiveness was, however, also explained by referring to Russia as a "tough case" uninterested in a negotiated solution. The lack of data on Russian perceptions constitutes a major limitation of this analysis. We have strong reason to believe that, like the Israeli elites, Russian elites also perceive the $\mathrm{EU}$ as both a biased and ineffective mediator, but we cannot prove this. Russia accepts the $\mathrm{EU}$ as a facilitating mediator, possibly in the hope that the EU may influence its Ukrainian partners, but does not seem willing to change its policies as a result of either diplomatic efforts or sanctions.

The EU was clearly perceived as a biased mediator by our Israeli respondents. Palestinian voices were less distinct: they stressed a perceived diversity among Member States, where some are clearly pro-Palestinian while others are not. Both parties to the conflict deemed the EU an ineffective mediator (as are its Member States), but this is not - even in Israel - associated with its perceived bias. Instead, our interviewees underlined the divided nature of the 
Union, the effects of economic and political crises, and the preponderant role of the Us in the conflict.

Comparing the two cases, it seems as if the weaker parties, which are also the parties favored by the EU, exhibit similarities. They appreciated the support from the EU, but did not see the Union as "biased enough," as support was perceived to be undermined by the EU's economic interests and internal disunity. The stronger parties experienced a strong negative EU bias (hypothetically in the Russian case) but still allowed the EU to play a mediator role. This may be linked to a widespread perception of the $\mathrm{EU}$ as a marginal and non-relevant actor without much real influence. Perceived bias is not openly associated with ineffectiveness, as it is in the end the us that "plays the first fiddle." Perceived mediator bias may, we argue, still lead to impaired effectiveness, especially in cases where the $\mathrm{EU}$ is a dominant actor.

More research on external parties' perceptions of EU mediation is needed. Is the EU also perceived as a biased mediator in other cases and to what effect? It could be argued that the Eu's hybrid nature - driven by both normative concerns and economic interests - renders it difficult for the Union to claim neutrality in most of the conflicts in which it is involved. Perceived partiality may therefore be a common theme. The cases we have studied indicate that perceived partiality is not necessarily associated with decreased effectiveness; effects are contingent on the situation. They also lead us to believe that the EU can at least play the role of facilitator and communicator. While a biased mediator may find that distrust from its partiality prevents it from engaging as formulator and manipulator, its special relation to one party may, at least in some instances, be an asset in bringing parties to the table.

\section{References}

Ademmer, Esther (2014). "Interdependence and EU-Demanded Policy Change in a Shared Neighbourhood." Journal of European Public Policy 22, 5: 671-689.

Aggestam, Lisbeth (2006). "Role Theory and European Foreign Policy: A Framework of Analysis," in O. Elgström and M. Smith, editors, The European Union's Roles in International Politics. Abingdon: Routledge.

Arensman, B., M. Van Wessel and D. Hilhorst (2017). "Does Local Ownership Bring About Effectiveness? The Case of a Transnational Advocacy Network." Third World Quarterly, 38: 1310-1326.

Bercovitch, Jacob (1992). "The Structure and Diversity of Mediation in International Relations," in J. Bercovitch and J. Rubin, editors, Mediation in International Relations. Houndmills: Macmillan. 
Bergmann, J. and A. Niemann (2015). "Mediating International Conflicts: The European Union as an Effective Peacemaker?" Journal of Common Market Studies 53, 5: 957-975.

Carnevale, P. and S. Arad (1996). "Bias and Impartiality in International Mediation," in J. Bercovitch, editor, Resolving International Conflicts. The Theory and Practice of Negotiation. Boulder, Co: Lynne Rienner.

Chaban, N. and M. Holland (2015). "EU External Perceptions: From Innovation to an Established Field of Study," in A. Aarstad et al., editors, The Sage Handbook of European Foreign Policy. London: Sage Publications Ltd.

De Galbert, Simond (2015). "The Impact of the Normandy Format on the Conflict in Ukraine: Four Leaders, Three Cease-fires, and Two Summits." Center for Strategic and International Studies. October 23. At: https://www.csis.org/analysis/impact -normandy-format-conflict-ukraine-four-leaders-three-cease-fires-and-two-summits.

Elgström, O. and N. Chaban (2015). "Studying External Perceptions of the EU: Conceptual and Methodological Approaches," in V. Bachmann and M. Müller, editors, Looking in from the Outside: Perceptions of the EU in Eastern Europe and SubSaharan Africa. Houndmills: Palgrave Macmillan.

Elgström, O. and M. Smith (2006). "Introduction," in O. Elgström and M. Smith, editors, The European Union's Roles in International Politics. Abingdon: Routledge.

Elgström, O., J. Bercovitch, and C. Skau (2003). "Regional Organisations and International Mediation: The Effectiveness of Insider Mediators." African Journal of Conflict Resolution 3, 1: 11-27.

Europa. "EU Sanctions against Russia over Ukraine Crisis." European Union Newsroom. At: https://europa.eu/newsroom/highlights/special-coverage/eu-sanctions -against-russia-over-ukraine-crisis_en.

Gordon, N. and S. Pardo (2015). "Normative Power Europe and the Power of the Local." Journal of Common Market Studies 53, 2: 416-427.

Harpaz, G. and A. Shamis (2010). "Normative Power Europe and the State of Israel: An Illegitimate EUtopia?" Journal of Common Market Studies 48, 3: 579-616.

Holsti, Kalevi J. (1970). "National Role Conceptions in the Study of Foreign Policy." International Studies Quarterly 14, 3: 233-309.

International Centre for Policy Studies (ICPS) (2015). Mapping of Dialogue Initiatives to Resolve the Conflict in Ukraine. At: http://icps.com.ua/assets/uploads/images/images/eu/mapping_of_dialogue_initiatives_eng_pdf

Jørgensen, Knud E. (2013). "Analysing the Performance of the European Union," in K. E. Jørgensen and K. V. Laatikainen, editors, Routledge Handbook on the European Union and International Institutions. Abingdon: Routledge.

Kanet, Roger E. (2015). “The Failed Western Challenge to Russia's Revival in Eurasia?” International Politics 52, 5: 503-522. 
Khader, Bichara (2013). “The European Union and the Palestinian Question (1957-2013): Soft Diplomacy and Hard Realities." Institut Medea Publications. At: http://cejm .udl.cat/wp-content/uploads/2013/10/khader_eu_palestine_1957_-2013_general.pdf.

Kleiboer, Marieke (1998). International Mediation: The Multiple Realities of ThirdParty Intervention. Boulder, co: Lynne Rienner.

Kostanyan, H. and S. Meister (2016). "Ukraine, Russia and the EU: Breaking the Deadlock in the Minsk Process." Center for European Policy Studies Working Document No. 423. At: https://www.ceps.eu/system/files/WD423KostanyanMeisterMinskII_o .pdf.

Kydd, Andrew (2003). "Which Side Are You On? Bias, Credibility, and Mediation." American Journal of Political Science 47, 4: 597-611.

Lucarelli, Sonia (2014). "Seen from the Outside: The State of the Art on the External Image of the EU." Journal of European Integration, 36:1-16.

Maoz, Z. and L. Terris (2006). "Credibility and Strategy in International Mediation." International Interactions 32: 409-440.

Mills, C. Wright (1956). The Power Elite. New York: Oxford University Press.

Müller, Patrick (2012). EU Foreign Policymaking Toward the Middle East Conflict: The Europeanization of National Foreign Policy. New York: Routledge.

Müller, Patrick (2014). "The Middle East Quartet and Informal Security Governance: Survival of the Unfittest?" International Peacekeeping 21, 4: 464-480.

Pardo, Sharon (2010). "Between Attraction and Resistance: Israeli Views of the European Union," in S. Lucarelli and L. Fioramonti, editors, External Perceptions of the European Union as a Global Actor. New York: Routledge.

Pardo, Sharon (2015). Normative Power Meets Israel: Perceptions and Realities. Lanham: Lexington Books.

Pardo, S. and J. Peters (2010). Uneasy Neighbors: Israel and the European Union. Lanham: Lexington Books.

Persson, Anders (2013). Defining, Securing and Building a Just Peace: The EU and the Israeli-Palestinian Conflict. Lund: Lund University, Department of Political Science.

Princen, Thomas (1992). Intermediaries in International Conflict. Princeton, NJ: Princeton University Press.

Reich, Arie (2015). "The European Neighbourhood Policy and Israel: Achievements and Disappointments." Journal of World Trade 49, 4: 619-642.

Richmond, Oliver (1998). “Devious Objectives and the Disputants' View of International Mediation: A Theoretical Framework." Journal of Peace Research 35, 6: 707-722.

Santoro, S. and R. Nasrallah (2010). "Conflict and Hope: The EU in the Eyes of Palestine," in S. Lucarelli and L. Fioramonti, editors, External Perceptions of the European Union as a Global Actor. Oxon: Routledge. 
Savun, Burcu (2008). "Information, Bias, and Mediation Success." International Studies Quarterly 52, 1: 25-47.

Shelest, Hanna (2016). "The Prospects of the European Union Mediation and Peacekeeping in the Eastern Partnership." ces Working Papers 8, 3: 473-489. At: http://www.ceswp.uaic.ro/articles/CESWP2016_VIII3_SHE.pdf.

Svensson, Isak (2009). "Who Brings Which Peace? Neutral versus Biased Mediation and Institutional Peace Arrangements in Civil Wars." Journal of Conflict Resolution 53, 3: 446-469.

Tocci, Nathalie (2002). "The Middle East Quartet and (In)effective Multilateralism." The Middle East Journal 67, 1: 29-44.

Tocci, N. (2009). "Firm in Rhetoric, Compromising in Reality: The EU in the IsraeliPalestinian Conflict." Ethnopolitics 8, 3: 387-401.

Touval, Saadia (1975). "Biased Intermediaries: Theoretical and Historical Considerations." Jerusalem Journal of International Affairs 1: 51-69.

Touval, Saadia (1982). The Peace Brokers. Princeton, NJ: Princeton University Press.

Touval, S. and I. W. Zartman, editors (1985). International Mediation in Theory and Practice. Boulder, co: Westview.

Touval, S. and I. W. Zartman (2007). "International Mediation in the Post-Cold War Era," in C. Crocker, F. Hampson and P. Aall, editors, Leashing the Dogs of War. Washington, DC: Us Institute of Peace Press.

Tsygankov, Andrei (2015). “Vladimir Putin's Last Stand: The Sources of Russia's Ukraine Policy." Post-Soviet Affairs 31, 4: 279-303.

Wallensteen, P. and I. Svensson (2014). "Talking Peace: International Mediation in Armed Conflicts." Journal of Peace Research 51, 2: 315-327.

Young, Oran R. (1967). The Intermediaries: Third Parties in International Crises. Princeton, NJ: Princeton University Press.

Zartman, I. William (2008). "Introduction: Bias, Prenegotiation and Leverage in Mediation." International Negotiation 13: 305-310. 